\title{
DROSERACEAE GLAND AND GERMINATION PATTERNS REVISITED: SUPPORT FOR RECENT MOLECULAR PHYLOGENETIC STUDIES
}

\author{
JOHN G. CONRAN $\bullet$ Centre for Evolutionary Biology and Biodiversity $\bullet$ Environmental Biology $\bullet$ School \\ of Earth and Environmental Sciences • Darling Building DP418 - The University of Adelaide • SA \\ 5005•Australia・john.conran@adelaide.edu.au \\ GUNTA JAUDZEMS $\bullet$ Department of Ecology and Evolutionary Biology $\bullet$ Monash University $\bullet$ Clayton \\ - Vic. $3168 \cdot$ Australia \\ NEIL D. HALLAM $\bullet$ Department of Ecology and Evolutionary Biology $\bullet$ Monash University $\bullet$ Clayton • \\ Vic. $3168 \cdot$ Australia
}

Keywords: Physiology: Aldrovanda, Dionaea, Drosera.

\section{Abstract}

Droseraceae germination and leaf gland and microgland character state patterns were re-examined in the light of new molecular phylogenetic relationships. Phanerocotylar germination is basal in the family, with cryptocotylar germination having evolved at least twice; once in Aldrovanda, and again in Drosera within the Bryastrum/Ergaleium clade. Gland patterns also support major clades; with the Bryastrum clade taxa having marginal and Rorella-type glands whereas the terminal branch of the Drosera clade had marginal glands and most of the clade possessed biseriate type 3 glands. The gland and germination patterns are supported by growth habit features, suggesting that the family and the main clades within Drosera in particular have undergone major adaptive radiations for these characters.

\section{Introduction}

Relationships between the genera and species of Droseraceae have been the subject of numerous studies, with a range of morphology-based systems produced, mainly using traditional characters such as habit, leaf-associated features and specialised propagation techniques (e.g. Planchon 1848; Diels 1906). Character evolution of traps has also been considered important in carnivorous plants (Juniper et al. 1989; Jobson \& Albert 2002) and glandular patterns (Seine \& Barthlott 1992, 1993; Länger et al. 1995) were considered important at the sectional level, as well as providing possible evidence of relationships and/or patterns with related families such as Plumbaginaceae (Wilson 1890; Schlauer 1997).

In addition, studies of characters such as cytology (e.g. Kondo 1976; Kondo \& Lavarack 1984), germination (Conran et al. 1997), pollen structure (Takahashi \& Sohma 1982) and phytochemisty (Culham \& Gornall 1994) have added to the overall understanding of relationships in the family, contributing to several proposed classification realignments (Marchant et al. 1982; Seine \& Barthlott 1994; Schlauer 1996).

Molecular sequence data were useful for showing the evolution of trap complexity in Lentibulariaceae (Jobson \& Albert 2002) and relationships within Nepenthaceae where convergent morphology had made phylogenetic interpretation difficult (Meimberg et al. 2001). Molecular phylogenetic information also allowed the exploration of snap trap evolution in Droseraceae through character mapping of trapping morphology and mechanisms onto clades (Cameron et al. 2002), as well as for exploring the development predisposition for, and possible loss of carnivory in the Caryophyllidae (Meimberg et al. 2000). The development of new molecular phylogenies within Droseraceae has helped to resolve some of the ongoing controversies, such as the position of Drosophyllum (and support for its removal from the family) and the position of morphologically unusual or "isolated" Drosera species (Albert et al. 1992; Williams et al. 1994; Rivadavia et al. 2003). However, one of the biggest advantages of these molecular phylogenies is to assist in the study of character evolution, as well as the evaluation of different character set patterns for their usefulness in supporting classification within the family and exploring evolution and biogeography. For example, the Droseraceae molecular data are supported in part by chromosome number and biogeographic patterns, suggesting support for a possible southern hemisphere African-Australian origin of the family (Rivadavia et al. 2003).

Accordingly, this study re-examines germination data for the family and combines them with sig- 
nificantly expanded leaf gland and microgland data to test the hypothesis that these characters show phylogenetically useful patterns under the revised molecular phylogeny for Droseraceae of Rivadavia et al. (2003).

\section{Materials and Methods}

Gland diversity was investigated using both light and scanning electron microscopy. Specimens for whole-mount examination were immersed in $26 \% \mathrm{vol} / \mathrm{vol}$ lactic acid until cleared, then mounted in lactic acid and examined under a transmission light microscope. Material for scanning electron microscopy was fixed in 5\% glutaraldehyde for 30 minutes, dehydrated through a graced ethanol series, critical point dried and coated using and Eiko IB. 5 ion sputter coater. Specimens were observed with a Hitachi S-570 scanning electron microscope at $5-15 \mathrm{kV}$, and the location and structure of any glands was classified relative to those reported by Seine \& Barthlott $(1992 ; 1993)$ and Länger et al. (1995).

Germination data from Conran et al. (1997), gland and microgland data from Seine \& Barthlott (1993), Länger et al. (1995), and our own unpublished gland/microgland data for 180 species, subspecies, varieties, cultivars and morphotypes of Drosera, Dionaea and Aldrovanda were assembled for each of the different character states at the sectional level. However, as the previous two studies did not code gland types in the same manner, direct comparison between them was difficult. In an attempt to reconcile their respective leaf microgland classifications, the data for their studies and ours are summarised at sectional level with the respective gland classifications indicated in Table 1 . These character state distributions were then mapped onto a condensed sectional-level cladogram derived from the clades obtained by Rivadavia et al. (2003), using the sectional classification of Schlauer (1996) and the clade-exploration program MacClade 3.06 (Maddison \& Maddison 1996). Phylogenetically useful patterns of character states were then discussed in terms of evolution within the family.

\begin{tabular}{|c|c|c|c|c|c|c|c|c|c|c|c|c|c|c|}
\hline Taxon & $\begin{array}{l}\text { No. of } \\
\text { taxa } \\
\text { xamined }\end{array}$ & St & $\mathrm{Ma}$ & $\begin{array}{c}\text { T1 } \\
\text { B, F, } \\
\text { bi }\end{array}$ & $\begin{array}{c}\text { T1 } \\
\text { E, G, } \\
\text { H, bi }\end{array}$ & $\begin{array}{l}\mathrm{T} 2 \\
\mathrm{bi}\end{array}$ & $\begin{array}{c}\text { T3 } \\
\text { C, bi }\end{array}$ & $\begin{array}{l}\mathrm{T} 4-5 \\
\mathrm{D}, \mathrm{mu}\end{array}$ & $\begin{array}{l}\mathrm{T} 6 \\
\mathrm{mu}\end{array}$ & $\begin{array}{l}\mathrm{T} 7-9 \\
\mathrm{I}, \mathrm{mu}\end{array}$ & $\begin{array}{c}\mathrm{T} 10-12 \\
\mathrm{mu}\end{array}$ & $\mathrm{Ge}$ & GC & $\mathrm{NC}$ \\
\hline Aldrovanda & 1 & 0 & 0 & $\mathrm{~F} 1$ & G1 & $\mathrm{a}$ & 0 & 0 & 0 & 0 & 0 & $\mathrm{CR}$ & 0 & 1 \\
\hline $\begin{array}{l}\text { Dionaea } \\
\text { Drosera }\end{array}$ & 1 & 0 & 0 & 0 & $\mathrm{H} 1$ & $\mathrm{a}$ & 0 & 0 & 0 & 0 & 0 & $\mathrm{HE}$ & 0 & 0 \\
\hline $\begin{array}{l}\text { Subgenus Arcturia } \\
\text { Subgenus Bryastrum }\end{array}$ & 1 & 1 & 0 & 0 & 0 & 0 & 0 & 0 & 0 & 1 & 0 & $\mathrm{PH}$ & 0 & 0 \\
\hline Section Bryastrum & 1 & 1 & 1 & 0 & 0 & 1 & 0 & 0 & 0 & 0 & 0 & CR & 0 & 0 \\
\hline Section Lamprolepis & 43 & 43 & 34 & B4 & E2 & 0 & 0 & 43 & 0 & 1 & 4 & CR & 0 & 0 \\
\hline $\begin{array}{l}\text { Subgenus Coelophylla } \\
\text { Subgenus Drosera }\end{array}$ & 1 & 1 & 1 & 0 & E1 & 0 & 0 & 1 & 0 & 0 & 0 & $\mathrm{CR}$ & 0 & 0 \\
\hline Section Arachnopus & 1 & 1 & 0 & 0 & 0 & 0 & 0 & 0 & 1 & 0 & 0 & $\mathrm{PH}$ & 0 & 0 \\
\hline Section Drosera & 26 & 26 & 21 & B8 & E3 & 1 & 15 & 0 & 0 & 1 & 3 & $\mathrm{PH}$ & 16 & 0 \\
\hline Section Oösperma & 16 & 16 & 13 & B5 & E4 & 0 & 10 & 0 & 0 & 2 & 0 & $\mathrm{PH}$ & 9 & 0 \\
\hline Section Prolifera & 3 & 3 & 0 & B2 & E1 & 0 & 0 & 0 & 1 & 0 & 0 & $\mathrm{HE}$ & 0 & 0 \\
\hline Section Psychophila & 2 & 2 & 0 & B2 & 0 & 0 & 0 & 0 & 0 & 0 & 0 & $\mathrm{PH}$ & 0 & 0 \\
\hline Section Ptycnostigma & 7 & 7 & 7 & 0 & E4 & 0 & 1 & 0 & 0 & 2 & 1 & $\mathrm{PH}$ & 1 & 0 \\
\hline Subgenus Ergaleium & & & & & & & & & & & & & & \\
\hline Section Ergaleium & 35 & 35 & 0 & B3 & E28 & 0 & 0 & 0 & 0 & 10 & 2 & CR & 0 & 0 \\
\hline Section Stolonifera & 8 & 8 & 0 & 0 & E6 & 0 & 0 & 0 & 0 & 4 & 0 & CR & 0 & 0 \\
\hline Section Erythrorhiza & 17 & 17 & 0 & 0 & E9 & 0 & 0 & 0 & 0 & 9 & 1 & CR & 0 & 0 \\
\hline Subgenus Lasiocephala & 9 & 9 & 4 & B8 & E1 & 0 & 0 & 0 & 0 & 0 & 0 & $\mathrm{CR}$ & 0 & 0 \\
\hline Subgenus Meristocaulis & 1 & 1 & 1 & 0 & 0 & 1 & 0 & 0 & 0 & 0 & 1 & $?$ & $?$ & $?$ \\
\hline Subgenus Phycopsis & 1 & 1 & 1 & 0 & E1 & 0 & 0 & 0 & 0 & 1 & 0 & $\mathrm{PH}$ & 0 & 0 \\
\hline Subgenus Regiae & 1 & 1 & 0 & 0 & 0 & 0 & 0 & 0 & 0 & 1 & 0 & $\mathrm{PH}$ & 0 & 0 \\
\hline Subgenus Stelogyne & 1 & 1 & 1 & 0 & 0 & 0 & 1 & 0 & 0 & 0 & 0 & $\mathrm{PH}$ & 0 & 0 \\
\hline Subgenus Thelocalyx & 2 & 2 & 2 & 0 & E2 & 0 & 0 & 2 & 1 & 1 & 0 & $\mathrm{PH}$ & 2 & 0 \\
\hline
\end{tabular}

Table 1: Numbers of taxa exhibiting gland and germination features for Droseraceae, summarised by genus, subgenus and section following Schlauer (1996) unless a section or species group was separated in Rivadavia et al. (2003): St = stalked central glands; $\mathrm{Ma}=$ stalked marginal unifacial glands; T1-T11 = sessile leaf microgland types as classified by Länger $e t$ al. (1995); B-I = sessile microgland types as classified by Seine \& Barthlott (1993); a = a related gland type not differentiated by Seine \& Barthlott (1993); bi = biseriate microglands; $\mathrm{mu}=$ multiseriate microglands; $\mathrm{Ge}=$ germination type $(\mathrm{P}=$ phanerocotylar, $\mathrm{C}=$ cryptocotylar, $\mathrm{H}=$ hemicrypotocotylar); $\mathrm{GC}=$ glandular cotyledons; $\mathrm{NC}=$ first leaves non-carnivorous. Gland data for subgenus Meristocaulis from Seine \& Barthlott (1993) and Länger et al. (1995). 

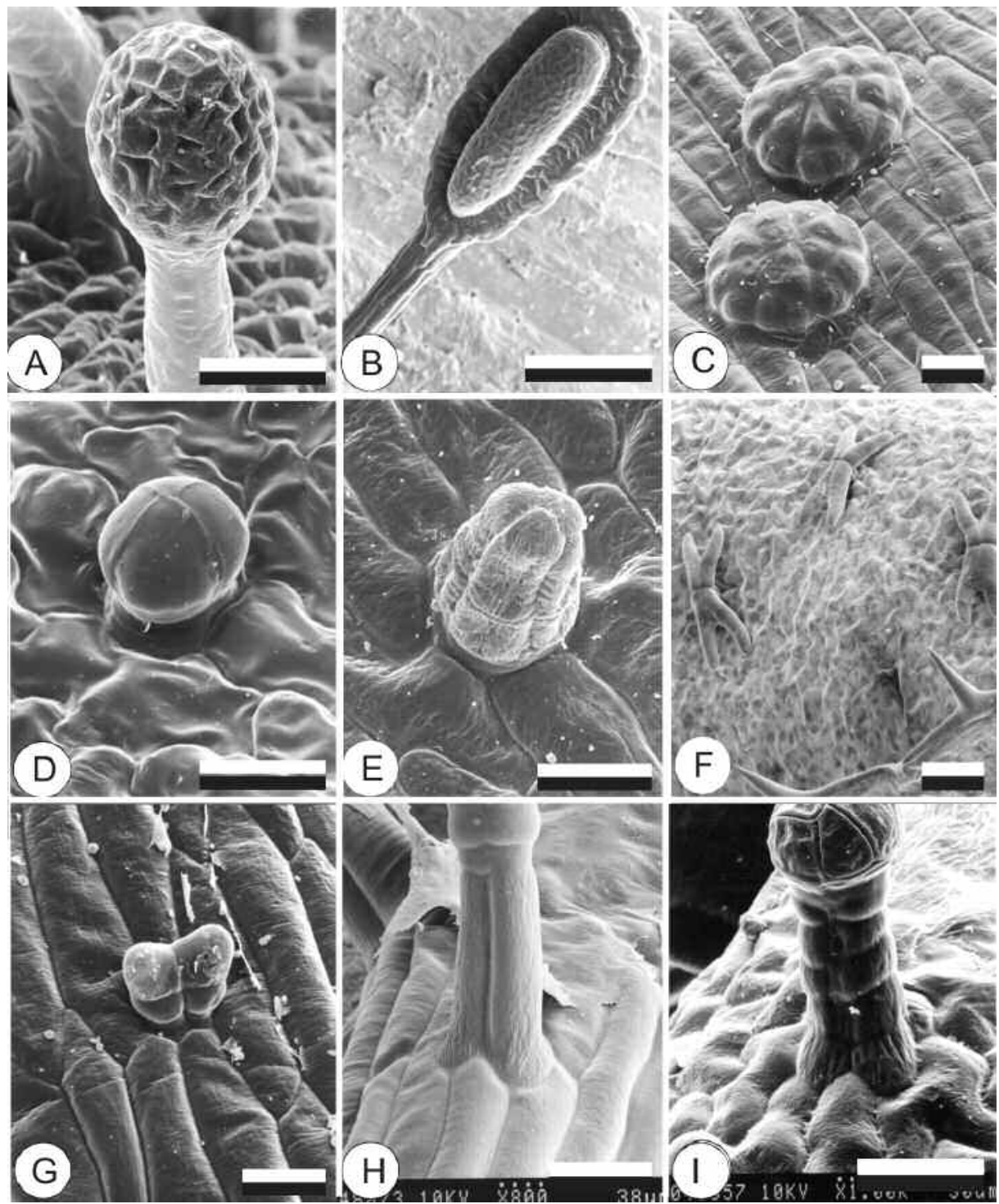

Figure 1: Droseraceae taxonomically informative gland types. A: Drosera trinervia Spreng. stalked gland; B: D. capillaris Poir. marginal unifacial gland; C: Dionaea muscipula Soland ex Ellis sessile multicellular glands; D: Drosera menziesii R.Br. ex DC. type 1B multiseriate gland; E: Drosera erythrorhiza Lindl. type 1E sessile multiseriate gland; F: Aldrovanda vesiculosa L. elongated sessile multiseriate glands; G: Drosera capillaris type 3 biseriate gland; $\mathrm{H}$ : Drosera sewelliae Diels type 4-5 sessile biseriate (Rorella-type) gland; I: Drosera andersoniana W.Fitzg. ex Ewart. \& White type 11 inflorescence gland. Scale bars $\mathrm{A}, \mathrm{B}=50 \mu \mathrm{m}, \mathrm{C}-\mathrm{I}=25 \mu \mathrm{m}$. 


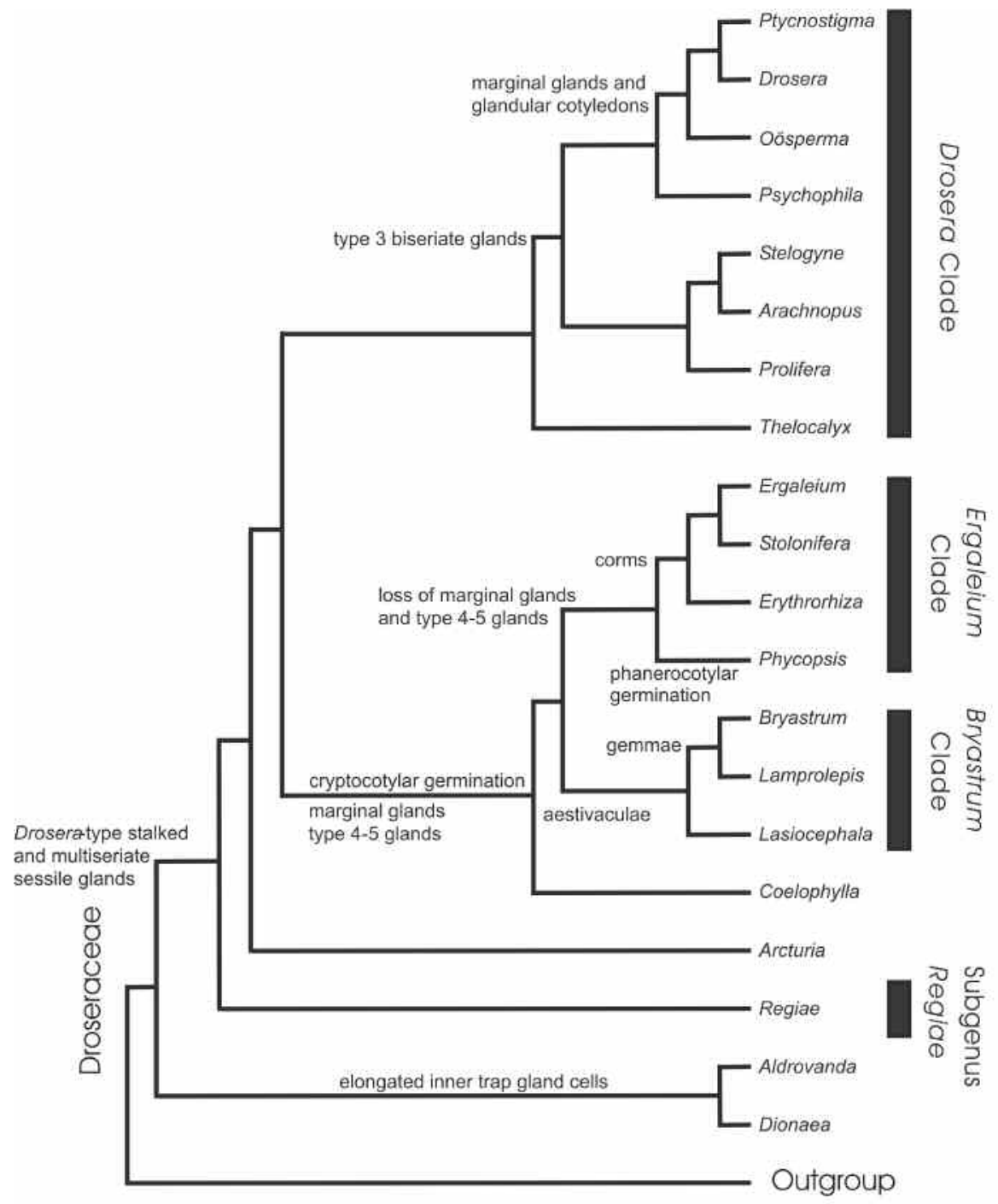

Figure 2. Condensed cladogram showing major groups derived from the molecular analysis of Rivadavia et al. (2003) and showing the relationship of the clades to various gland, germination and asexual reproductive features. 
Gland patterns showed that Drosera was distinguished from its relatives by the presence of multiseriate sessile glands in addition to the distinctive Drosera-type stalked glands. All taxa possessing Type 3 biseriate glands (sensu Länger et al. (1995)) were located within the Drosera clade, and those with marginal glands were in a terminal clade containing sections Drosera, Oösperma and Ptycnostigma, as well as in the taxa now comprising the Bryastrum clade. The biseriate glands with elongated basal cells classed as Types 4 and 5 by Länger et al. (1995) were listed as Rorella-type glands by Seine \& Barthlott (1993) because they were seen in subgenus Bryastrum (=Rorella auct. non Hall. ex All.: N.Marchant). The expanded data confirm this, with all taxa possessing these glands being members of the Bryastrum clade sensu Schlauer (1996) possessing these glands, as well as subgenus Coelophylla (D. glanduligera Lehm.) which was basal to the Bryastrum/Ergaleium clade pair.

When mapped onto the revised cladogram of Rivadavia et al. (2003), cryptocotylar germination becomes a synapomorphy for the clade representing the subgenera Bryastrum, Coelophylla, and Ergaleium (see Figure 2). With the exception of section Phycopsis (D. binata Labill.) all species in the clade so far germinated are cryptocotylar. The basal Drosera taxa are phanerocotylar with eglandular cotyledons, whereas those species that have glands on the cotyledons are restricted to the terminal clade containing sections Drosera, Oösperma and Ptycnostigma. These patterns are also supported by other features such as growth form (e.g. the tuberous habit of the Ergaleium clade taxa), distinctive petiolate leaves and the formation of summer-dormant aestivaculae (Gaff 1981) shared between sections Lamprolepis, Bryastrum and Lasiocephala. There is also a propensity of cryptocotylar germination in dry-land habitat species (Pate \& Dixon 1982) and those with asexual reproduction such as gemmae and tubers (Karlsson \& Pate 1992) as seen in members of the cryptocotylar Ergaleium and Bryastrum clades.

\section{Discussion}

Although some of the taxa studied here for gland data were also reported by Seine \& Barthlott (1993) and Länger et al. (1995), our study provides data for a further 107 species, varieties, cultivars and morphotypes. In particular, we included many more taxa from sections Lamprolepis and Lasiocephala, so that between these three studies, most taxa within the family have now been surveyed. Our gland survey results for the additional taxa largely agree with those of the earlier studies. The Ergaleium clade was uniform in lacking marginal unifacial or spoon glands, as well as only possessing multiseriate microglands. There was considerable variability in inter-taxon gland types in the Drosera and Bryastrum clades. As with the earlier studies, there were both taxa with and without, marginal unifacial glands, but the dichotomy into taxa with multiseriate versus biseriate microglands was also observed.

Schlauer (1997) noted that gland studies in angiosperms related to Droseraceae were not new. Dionaea, Aldrovanda, Drosophyllum, Polygonum (Lersten \& Curtis 1992), Nepenthaceae (Fahn 1979), Frankeniaceae, Plumbaginaceae and Tamaricaceae (Wilson 1890) all possess flat modified multicellular glands of sub-epidermal origin, which in Plumbaginaceae at least are thought to be derived from calcium carbonate-secreting Mettenian glands and developed into mucilage glands via intermediate forms. There are also symmetrical multicellular stalked glands, both vascularised and non-vascularised in Plumbaginaceae, Ancistrocladaceae and Dioncophyllaceae that are similar to those in Drosera and Drosophyllum. This indicates that the precursors for the trapping and glandular structures seen in Droseraceae are widespread in nearby outgroup Carophyllid families, possibly helping to explain the multiple development of carnivory within the group, or as suggested by Meimberg et al. (2000), the loss of carnivory in Ancistrocladaceae and most Dioncophyllaceae. This development is further seen within Droseraceae, where the basal taxa (section Arcturia and subgenus Regiae) are those with multicellular glands and unspecialised stalked glands, whereas the more derived Drosera and Bryastrum clades are where biseriate glands developed. Unifacial marginal glands seem to have developed several times, but also appear to have been lost secondarily in subgenus Ergaleium. Similarly, glandular cotyledons although found in the terminal Drosera clade, are also widespread in the outgroup families suggesting that this feature is ancestral and that its absence in various Droseraceae taxa possibly represents multiple loss.

Subgenus Meristocaulis was not included in the molecular phylogeny and its germination pattern is not known. The gland patterns (Table 1) are ambiguous, with marginal glands and Type T2 biseriate 
and T11-12 multiseriate sessile glands. This pattern is seen in members of both the Drosera and Bryastrum clades, so that in the absence of germination data, the position of Meristocaulis is still uncertain.

Germination patterns show that cryptocotyly has apparently evolved several times in the family (Fig. 2). In comparison with outgroup families; although Drosophyllaceae are cryptocotylar, the other related families (Tamaricaceae, Nepenthaceae, Polygonaceae, Plumbaginaceae and Limoniaceae) are all phanerocotylar, which is also the most common germination condition in the Caryophyllales (Clifford 1981; Clifford 1991). Conran et al. (1997) also described the germination pattern of hemicryptocotyly, where the cotyledons emerge partially from the testa and are photosynthetic, but the apices remain enclosed in the seed. This pattern, seen in both Dionaea and D. adelae F.Muell. seedlings, seems to be an intermediate stage between crypto- and phanerocotyly. Cryptocotyly is a condition generally associated with large-seeded taxa, often from rainforests, and its occurrence in Droseraceae is considered unusual (Clifford 1984). The fact that it occurs in Drosophyllum, Aldrovanda and the Ergaleium/Bryastrum clade in Drosera suggests that there is an ecological association, as these are the taxa where there is often a need for long-term seed dormancy. This may be due to fire- (e.g. Ortega Olivencia et al. 1995 for Drosophyllum) or inundation-triggered germination (e.g. Kozschinski 1886 in the case of Aldrovanda). This applies especially in SW Western Australia where both summer fire or smoke exposure and then cool moist winter conditions are needed to stimulate germination in many angiosperm taxa including both Byblidaceae and some Droseraceae (e.g. Bell et al. 1993; Roche et al. 1998; Wills \& Read 2002). Accordingly, the evolution of a larger seed reserve with a smaller embryo may be an advantage for long-term survival of these small seeds until environmental conditions are right for germination.

Seine \& Barthlott (1994) and Conran et al. (1997) noted that there were gland and germination patterns supporting classification changes in Droseraceae, and the molecular data support the placement of Ptycnostigma and Stelogyne with Drosera and Oösperma (along with sections Arachnopus, Prolifera, Psychophila, and subgenus Thelocalyx) in the phanerocotylar Drosera clade (Rivadavia et al. (2003)). Similarly, the taxa representing the Bryastrum clade are also united by Rorella-type glands and cryptocotylar germination, agreeing with many of the changes suggested by Conran et al. (1997), as well as some of the realignments of Schlauer (1996). Nevertheless, a number of the latter's subgenera could be returned to sectional level within expanded subgenera representing the Drosera, Bryastrum and Ergaleium clades. These data show that the molecular clades have an underlying basis in both anatomy and trap evolution, but also in ancestral ecological choices - the linkage in Drosera of dryland-growing, asexually reproductive taxa with cryptocotylar germination, for example, shows that ecological adaptation seems to have been a major driving force for evolution within Droseraceae.

\section{Acknowledgements}

The Department of Botany (now Department of Ecology and Evolutionary Biology), Monash University and the School of Earth and Environmental Sciences, University of Adelaide are thanked for resources to undertake this study.

\section{References:}

Albert, V.A., Williams, S.E., and Chase, M.W. 1992. Carnivorous plants: Phylogeny and structural evolution. Science 257: 1491-1495.

Bell, D.T., Plummer, J.A., and Taylor, S.K. 1993. Seed germination ecology in southwestern Western Australia. Bot. Rev. 59: 24-73.

Cameron, K.M., Wurdack, K.J., and Jobson, R.W. 2002. Molecular evidence for the common origin of snap-traps among carnivorous plants. Amer. J. Bot. 89: 1503-1509.

Clifford, H.T. 1981. Seedlings in the Australian flora. Vic. Nat. 98: 75-79.

Clifford, H.T. 1984. Cryptocotyly in Australian dicotyledons. Fl. Males. Bull. 37: 49-53.

Clifford, H.T. 1991. Germination patterns in dicotyledons. Aliso 13: 207-213.

Conran, J.G., Jaudzems, G., and Hallam, N.D. 1997. Droseraceae germination patterns and their taxonomic significance. Bot. J. Linn. Soc. 123: 211-233.

Culham, A., and Gornall, R.J. 1994. The taxonomic significance of naphthoquinones in the Droseraceae. Biochem. Syst. Ecol. 22: 507-515.

Diels, L. 1906. Droseraceae. Pp. 1-136 in A. Engler (ed.). Das Pflanzenreich Vol. 4. Leipzig.

Fahn, A. 1979. Secretory Tissues in Plants. New York. 
Gaff, D.F. 1981. The biology of resurrection plants. Pp. 114-146 in J. Pate and A.J. McComb (eds). The Biology of Australian Plants. Nedlands.

Jobson, R.W., and Albert, V.A. 2002. Molecular rates parallel diversification contrasts between carnivorous plant sister lineages. Cladistics 18: 127-136.

Juniper, B.E., Robins, R.J., and Joel, D.M. 1989. Carnivorous Plants. London.

Karlsson, P.S. and Pate, J.S. 1992. Resource allocation to asexual gemma production and sexual reproduction in south-western Australian pygmy and micro stilt-form species of sundew (Drosera spp. Droseraceae). Austral. J. Bot. 40: 353-364.

Kondo, K. 1976. A cytotaxonomic study in some species of Drosera. Rhodora 78: 532-541.

Kondo, K., and Lavarack, P.S. 1984. A cytotaxonomic study of some Australian species of Drosera L. (Droseraceae). Bot. J. Linn. Soc. 88: 317-333.

Kozschinski, S. 1886. Über die Samen der Aldrovanda vesiculosa L. Bot. Centralb. 27: 302-304; 334335.

Länger R., Pein, I., and Kopp, B. 1995. Glandular hairs in the genus Drosera (Droseraceae). Pl. Syst. Evol. 194: 163-172.

Lersten, N.R., and Curtis, J.D. 1992. Foliar anatomy of Polygonum (Polygonaceae): survey of epidermal and selected internal structures. Pl. Syst. Evol. 182: 71-106.

Maddison, W.P., and Maddison, D.R. 1996. MacClade Version 3.06. Sunderland MA.

Marchant, N., Aston, H.I., and George, A.S. 1982. Droseraceae. Pp. 9-64 in A.S. George (ed.). Flora of Australia Vol. 8. Canberra.

Meimberg, H., Dittrich P., Bringmann G., Schlauer, J., and Heubl, G. 2000. Molecular phylogeny of Caryophyllidae s.l. based on matK sequences with special emphasis on carnivorous taxa. Pl. Biol. 2: 218-228.

Meimberg, H., Wistuba, A., Dittrich, P., and Heubl, G. 2001. Molecular phylogeny of Nepenthaceae based on cladistic analysis of plastid trnK intron sequence data. Pl. Biol. 3: 164-175.

Ortega Olivencia, A., Carrasco Claver, J.P., and Devesa Alcaraz, J.A. 1995. Floral and reproductive biology of Drosophyllum lusitanicum (L.) Link (Droseraceae). Bot. J. Linn. Soc. 118: 331-351.

Pate, J.S., and Dixon, K.W. 1982. Tuberous, Cormous and Bulbous Plants. Nedlands, Western Australia.

Planchon, J.É. 1848. Sur la familie des Droséracées. Ann. Sci. Nat. Bot. sér. 3. 9: 285-309.

Rivadavia, F., Kondo, K., Kato, M., and Hasebe, M. 2003. Phylogeny of the sundews, Drosera (Droseraceae), based on chloroplast $r b c \mathrm{~L}$ and nuclear $18 \mathrm{~S}$ ribosomal DNA sequences. Amer. J. Bot. 90: 123-130.

Roche, S., Dixon, K., and Pate, J. 1998. For everything a season: Smoke-induced seed germination and seedling recruitment in a Western Australian Banksia woodland. Austral. J. Ecol. 23: 111-20.

Schlauer, J. 1996. A dichotomous key to the genus Drosera L. (Droseraceae). Carniv. Pl. Newslett. 25 : 67-88.

Schlauer, J. 1997. "New" data relating to the evolution and phylogeny of some carnivorous plant families. Carniv. Pl. Newslett. 26: 34-38.

Seine, R., and Barthlott, W. 1992. Ontogeny and morphological quality of the marginal bristles of Dionaea muscipula Ellis (Droseraceae Salisb.). Beit. Biol. Pfl. 67: 289-294.

Seine, R., and Barthlott, W. 1993. On the morphology of trichomes and tentacles of Droseraceae Salisb. Beit. Biol. Pfl. 67: 345-366.

Seine, R., and Barthlott, W. 1994, Some proposals on the infrageneric classification of Drosera L. Taxon 43: 583-589.

Takahashi, H., and Sohma, K. 1982. Pollen morphology of the Droseraceae and its related taxa. Sci. Rep. Tohoku Univ., 4th series, Biology 38: 81-156.

Williams, S.E., Albert, V.A., and Chase, M.W. 1994. Relationships of Droseraceae: A cladistic analysis of $r b c \mathrm{~L}$ sequence and morphological data. Amer. J. Bot. 81: 1027-1037.

Wills, T.J., and Read, J. 2002. Effects of heat and smoke on germination of soil-stored seed in a southeastern Australian sand heathland. Austral. J. Bot. 50: 197-206.

Wilson, J. 1890. The mucilage- and other glands of the Plumbagineae. Ann. Bot. 4(14): 231-258. 